\title{
The Mineralogy and Petrology of Manganese-Rich Rocks From St. Marcel, Piedmont, Italy*
}

\author{
Philip Brown, Eric J. Essene, and Donald R. Peacor \\ Department of Geology and Mineralogy, The University of Michigan, Ann Arbor, MI 48109, USA
}

\begin{abstract}
Manganese-rich metamorphic rocks containing violan from St. Marcel, Piedmont, Italy formed under blueschist facies conditions, yielding an unusual suite of minerals including omphacite-albitequartz, braunite, microcline, hollandite, piedmontite, and strontian calcite. Violan, a violet-colored pyroxene, is shown to be a manganoan omphacite having a primitive unit cell, and is found in the same sample as diopside, possibly indicating a solvus relation. A manganoan phlogopite and a celadonitic muscovite coexist in one sample with microcline. The occurrence of celadonite and phlogopite is the first from the blueschist facies and the celadonite component in the dioctahedral mica is buffered at a maximum by coexistence with phlogopite, microcline, and quartz. Various phase relations are used to establish the $P$ and $T$ of equilibration at $8 \pm 1 \mathrm{kbar}$ and $300 \pm 50^{\circ} \mathrm{C}$, respectively, while the oxygen fugacity is shown to have been very high, for these temperatures, as consistent with braunite + quartz and the presence of piedmontite.
\end{abstract}

\section{Introduction}

Manganese-rich rocks from St. Marcel, Val d'Aosta, Italy have long been known as a source of piedmontite, with associated minerals including braunite, quartz, violan (a violet clinopyroxene), alurgite (a manganoan phengite), sphene and white fibrous tremolite (Dana, 1892). The rocks are closely associated with a blueschist facies paragenesis which includes the minerals lawsonite and glaucophane (Van der Plas, 1959; Lorenzoni, 1965; Ernst, 1973). As part of a study of manganese pyroxenes including blue clino-

* Contribution No. 343, from the Mineralogical Laboratory, Department of Geology and Mineralogy, The University of Michigan, Ann Arbor, MI 48109, USA pyroxenes from Balmat, N.Y., we examined specimens of violan-bearing rocks from the Mineralogical Collection of The University of Michigan which originated from St.Marcel. Our initial examination showed that the violan is an omphacite in the same sample with diopside and thus apparently exhibiting a solvus relation. We have therefore examined the mineralogy and crystal chemistry of the specimens at our disposal in some detail, in order to define the relations between the pyroxenes and other phases.

The specimens were initially examined using standard optical, X-ray diffraction and energy-dispersive electron microprobe techniques, resulting in identification of the following assemblages for the three available samples:

Sample 1: manganoan omphacite-braunite-quartz-albite-piedmontite

Sample 2: manganoan omphacite-diopside-quartzalbite-microcline-braunite-hollandite-strontian calcite-apatite-piedmontite-manganoan phengite-manganoan phlogopite

Sample 3: manganoan omphacite braunite-quartz-albite-piedmontite-strontain calcite.

The description of our results below is divided into a mineralogical study of the pyroxenes, micas, and other minerals, followed by petrologic interpretations of the assemblages. Optical properties of selected minerals are listed in Table 1 and chemical analyses in Table 2.

\section{Pyroxenes}

The violan matches descriptions of other material from the locality and has a striking, deep violet color in hand specimen. In thinsection it is pleochroic in violets and blues (Table 1) as reminiscent of glaucophane. Analyses of violan as tabulated in Doelter (1912) and Hintz (1897) seldom yield a stoichiometric pyroxene formula and appear to have been obtained from impure material. One 
Table 1. Optical Properties of St. Marcel Minerals

\begin{tabular}{|c|c|c|c|}
\hline Mineral & Optic angle & Pleochroism & Other \\
\hline $\begin{array}{l}\text { Manganoan } \\
\text { Omphacite }\end{array}$ & $2 V_{z}=65-69^{\circ}$ & $\begin{aligned} X & =\text { pink-violet } \\
Y & =\text { salmon-pink } \\
Z & =\text { pink-blue }\end{aligned}$ & $\begin{array}{l}r>v \\
X<Y<Z\end{array}$ \\
\hline $\begin{array}{l}\text { Manganoan } \\
\text { Diopside }\end{array}$ & $2 V_{z}=60-65^{\circ}$ & $\begin{array}{l}X=\text { yellow-violet } \\
Y=\text { violet } \\
Z=\text { blue-purple }\end{array}$ & $\begin{array}{l}r>v \\
X<Y<Z\end{array}$ \\
\hline $\begin{array}{l}\text { Manganoan } \\
\text { Phengite }\end{array}$ & $\begin{array}{l}2 V_{x}=0-2^{\circ} \\
\text { (up to } 15^{\circ} \\
\text { if strained) }\end{array}$ & $\begin{array}{l}X=\text { pink } \\
Y=\text { light-salmon } \\
Z=\text { yellow }\end{array}$ & $\begin{array}{l}X>Y>Z \\
\beta=1.600\end{array}$ \\
\hline $\begin{array}{l}\text { Manganoan } \\
\text { Phlogopite }\end{array}$ & $2 V_{x}=85-90^{\circ}$ & $\begin{array}{l}X=\text { orange-brown } \\
Y=\text { yellow-orange } \\
Z=\text { light-olive }\end{array}$ & $\begin{array}{l}X>Y>Z \\
\beta=1.625\end{array}$ \\
\hline Piedmontite & & $\begin{array}{l}X=\text { yellow } \\
Y=\text { golden-orange } \\
Z=\text { crimson-red }\end{array}$ & $X<Y<Z$ \\
\hline
\end{tabular}

analysis (number 1, p. 1116, in Hintz's compilation does appear to be a stoichiometric omphacite with a composition in terms of end members of $\mathrm{Jd}_{39} \mathrm{Wo}_{26} \mathrm{En}_{27} \mathrm{Fs}_{4} \mathrm{Rh}_{4}{ }^{1}$. All the reported analyses do show the presence of substantial $\mathrm{Na}$ and $\mathrm{Al}$ and up to $2.5 \mathrm{wt} \%$ $\mathrm{MnO}$. Our wavelength dispersive electron microprobe analyses (Table 2 and Fig. 1) show that the violan is a manganoan omphacite with a composition of:

$\mathrm{Jd}_{35-50} \mathrm{Ac}_{0-15} \mathrm{Wo}_{20-30} \mathrm{En}_{20-30} \mathrm{Fs}_{0-4} \mathrm{Rh}_{1-3}$.

The $\mathrm{Na}$ and $\mathrm{Ca}$ sum to only $95 \pm 5 \%$ of the M2 site thus suggesting some substitution of $\mathrm{Mn}$ or $\mathrm{Fe}$, as well. The occurrence of omphacite in the blueschist facies with $\mathrm{Na} / \mathrm{Na}+\mathrm{Ca}$ between 0.4 and 0.6 suggests that omphacite has cation ordering and a primitive unit cell (Clark and Papike, 1968). Single crystal X-ray techniques were therefore used and these indeed showed the occurrence of the weak extra reflections which require that the space group is $P 2$ or $P 2 / n$. An X-ray powder diffractometer pattern was obtained using calcite as an internal standard, and data from this pattern is listed in Table 3. Cell parameters were refined using the program LCLSQ (Burnham, 1961), yielding the values $a=9.563(4), b=8.755$ (2), $c=5.251$ (2) $\AA$, and $\beta=106.93(4)^{\circ}$. These parameters are similar to those given by Clark and Papike (1968) for an omphacite of composition $\mathrm{Jd}_{50} \mathrm{Di}_{50}$.

Of greatest interest is the occurrence of both diopside and omphacite in sample no. 2. The pyroxenes are nearly indistinguishable in thin section, both exhibiting violet pleochroism. They are readily differentiated using energy-dispersive electron microprobe analysis, however. The results using this technique show that diopside grains are in contact with grains of violan, with no evidence of zoning, replacement or other disequilibrium relations. Attempts to map the exact textural relations between the phases using wavelength dispersive techniques were unfortunately not successful, as the contrast between grains of each using any given wavelength was not well-defined. Both pyroxenes are somewhat heterogeneous (Fig. 1) as is typical of low temperature pyroxenes (Essene and Fyfe, 1967). The jadeite component erratically varies from $\mathrm{Jd}_{3}$ to $\mathrm{Jd}_{12}$ in diopside, and from $\mathrm{Jd}_{35}$ to $\mathrm{Jd}_{50}$ in the omphacite in this sample.

These data are consistent with a possible solvus between $C$-centered diopside and primitive omphacite. Miscibility gaps have been

\footnotetext{
$1 \quad J d=$ jadeite, $A c=$ acmite, $W o=\mathrm{Ca}_{2} \mathrm{Si}_{2} \mathrm{O}_{6}, E n=\mathrm{Mg}_{2} \mathrm{Si}_{2} \mathrm{O}_{6}, F s$ $=\mathrm{Fe}_{2} \mathrm{Si}_{2} \mathrm{O}_{6}, R h=\mathrm{Mn}_{2} \mathrm{Si}_{2} \mathrm{O}_{6}$
}

Table 2. Representative Electron Microprobe Chemical Analyses. All analyses were obtained using an ARL-EMX microprobe with PET, LiF, and TAP crystal spectrometers. An Ortex current digitizer was used to stabilize the beam current. An accelerating voltage of $15 \mathrm{Kv}$ and sample current of $0.008-0.01$ microamps were used in all analyses. Standards are all well characterized natural silicates, reducing the correction factors in the data reduction program, EMPADR VII

\begin{tabular}{lccrrrrr}
\hline & $1 \mathrm{a}$ & $1 \mathrm{~b}$ & \multicolumn{1}{c}{2} & \multicolumn{1}{l}{3} & \multicolumn{1}{c}{4} & \multicolumn{1}{l}{5} & \multicolumn{1}{c}{6} \\
\hline $\mathrm{SiO}_{2}$ & 56.42 & 57.13 & 58.38 & 58.84 & 44.76 & 56.10 & 9.82 \\
$\mathrm{TiO}_{2}$ & - & - & 0.03 & 0.03 & 0.38 & 0.24 & - \\
$\mathrm{Al}_{2} \mathrm{O}_{3}$ & 2.15 & 8.55 & 11.51 & 8.88 & 10.47 & 18.98 & 0.17 \\
$\mathrm{Fe}_{2} \mathrm{O}_{3}$ & - & 1.04 & - & 3.12 & 0.31 & 0.63 & 0.32 \\
$\mathrm{FeO}$ & 1.67 & 0.31 & 0.89 & - & - & - & - \\
$\mathrm{Mn} \mathrm{O}_{3}$ & - & - & - & - & - & 1.29 & 75.50 \\
$\mathrm{MnO}$ & 0.63 & 1.13 & 0.85 & 0.71 & 4.09 & 0.36 & 11.31 \\
$\mathrm{MgO}$ & 16.96 & 10.85 & 9.16 & 8.95 & 24.10 & 6.75 & 1.01 \\
$\mathrm{CaO}$ & 21.13 & 14.26 & 12.79 & 12.18 & - & - & 0.40 \\
$\mathrm{Na}_{2} \mathrm{O}$ & 1.24 & 5.90 & 6.78 & 7.62 & 0.15 & 0.03 & - \\
$\mathrm{K}_{2} \mathrm{O}$ & - & - & - & - & 9.99 & 11.20 & - \\
$\mathrm{H}_{2} \mathrm{O}^{+}$ & - & - & - & - & 3.12 & 4.01 & - \\
$\mathrm{F}$ & - & - & - & - & 0.55 & 0.05 & - \\
\hline
\end{tabular}

\begin{tabular}{lccccccc}
\hline Total & 100.20 & 99.17 & 100.39 & 100.33 & 97.92 & 99.64 & 98.53 \\
$\mathrm{O}=\mathrm{F}$ & - & - & - & - & 0.25 & 0.02 & - \\
\hline Total & 100.20 & 99.17 & 100.39 & 100.33 & 97.67 & 99.62 & 98.53
\end{tabular}

\begin{tabular}{|c|c|c|c|c|c|c|c|}
\hline $\mathrm{Si}$ & 2.02 & 2.03 & 2.03 & 2.05 & 6.46 & 7.45 & 0.99 \\
\hline$A 1^{\mathrm{IV}}$ & - & - & - & - & 1.54 & 0.55 & 0.02 \\
\hline $\mathrm{Al}^{\mathrm{VI}}$ & 0.09 & 0.38 & 0.47 & 0.37 & 0.24 & 2.42 & - \\
\hline $\mathrm{Ti}$ & - & - & - & - & 0.05 & 0.03 & - \\
\hline $\mathrm{Fe}^{+3}$ & - & 0.03 & - & 0.08 & 0.04 & 0.06 & 0.03 \\
\hline $\mathrm{Mn}^{+} 3$ & - & - & - & - & - & 0.13 & 6.01 \\
\hline $\mathrm{Fe}^{+2}$ & 0.05 & 0.01 & 0.03 & - & - & - & - \\
\hline $\mathrm{Mn}^{+2}$ & 0.02 & 0.03 & 0.03 & 0.02 & 0.50 & 0.04 & 0.75 \\
\hline $\mathrm{Mg}$ & 0.91 & 0.58 & 0.48 & 0.47 & 5.18 & 1.33 & 0.15 \\
\hline $\mathrm{Ca}$ & 0.81 & 0.54 & 0.48 & 0.46 & - & - & 0.04 \\
\hline $\mathrm{Na}$ & 0.09 & 0.41 & 0.46 & 0.52 & 0.05 & 0.01 & - \\
\hline $\mathrm{K}$ & - & - & - & - & 1.84 & 1.90 & - \\
\hline $\mathrm{OH}^{-}$ & - & - & - & - & 3.00 & 3.98 & - \\
\hline $\mathrm{F}$ & - & - & - & - & 0.23 & 0.02 & - \\
\hline $\mathrm{O}$ & 6.00 & 6.00 & 6.00 & 6.00 & 20.77 & 20.00 & 12.00 \\
\hline $\mathrm{Jd}$ & 9 & 38 & 48 & 39 & & & \\
\hline $\mathrm{Ac}$ & & 3 & & 9 & & & \\
\hline 2Wo & 41 & 27 & 24 & 25 & & & \\
\hline $2 \mathrm{En}$ & 46 & 29 & 24 & 26 & & & \\
\hline $2 \mathrm{Fs}$ & 3 & 1 & 2 & & & & \\
\hline $2 \mathrm{Mn}$ & 1 & 2 & 2 & 1 & & & \\
\hline
\end{tabular}

$1 \mathrm{a}$ and $1 \mathrm{~b}=$ Touching diopside and omphacite from \#2

$2=$ Omphacite from \#1

$3=$ Iron omphacite from \#1

$4=$ Manganoan phlogopite (yellow mica)

$5=$ Manganoan phengite (pink mica)

$6=$ Braunite from \# 1

previously proposed as existing in the $\mathrm{Di}-\mathrm{Jd}$ system by Bell and Davis (1964, 1965), Coleman and Clark (1968) and Champness (1973). Bell and Davis proposed a wide miscibility gap between $\mathrm{Jd}_{90} \mathrm{Di}_{10}$ and $\mathrm{Jd}_{10} \mathrm{Di}_{90}$ based on unreversed experiments at high. $P-T$, even though Kushiro (1964) working on similar pyroxenes with similar equipment in the same laboratory reported complete 


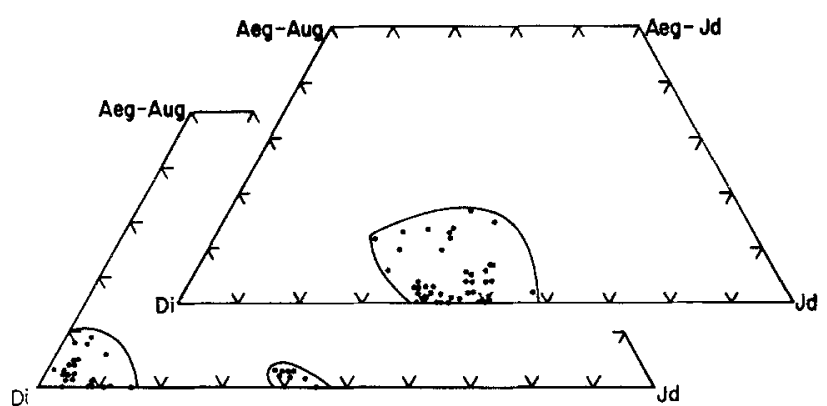

Fig. 1. Violan and coexisting omphacite-diopside analyses plotted on a portion of the Diopside-Jadeite-Acmite diagram (after Essene and Fyfe, 1967)

Table 3. Powder Diffration Data for Omphacite

\begin{tabular}{lllr}
\hline$h k l$ & $d$ (calc) & $d$ (obs) & $I$ \\
\hline $110^{\mathrm{b}}$ & 6.33 & 6.34 & 15 \\
$020^{\mathrm{b}}$ & 4.38 & 4.38 & 40 \\
$021^{\mathrm{b}}$ & 3.30 & 3.30 & 10 \\
$220^{\mathrm{b}}$ & 3.16 & 3.16 & 45 \\
$22 \overline{1}^{\mathrm{b}}$ & 2.958 & 2.959 & 100 \\
$13 \overline{1}$ & 2.529 & 2.527 & 30 \\
$002^{\mathrm{b}}$ & 2.512 & 2.512 & 25 \\
$221^{\mathrm{b}}$ & 2.462 & 2.461 & 40 \\
$311^{\mathrm{b}}$ & 2.246 & 2.246 & 15 \\
$42 \overline{1}$ & 2.075 & 2.075 & 10 \\
$40 \overline{2}$ & 2.007 & 2.006 & 20 \\
$041^{\mathrm{b}}$ & $2.007\}$ & & \\
202 & 1.973 & 1.972 & 5 \\
510 & 1.791 & 1.792 & 10 \\
$150^{\mathrm{b}}$ & 1.720 & 1.720 & 15 \\
$53 \overline{1}^{\mathrm{b}}$ & 1.596 & 1.596 & 20 \\
\hline
\end{tabular}

* Observed values were obtained using a Phillips Diffractometer employing $\mathrm{CuK}_{\alpha}$ radiation and a $1 \%$ min scan rate. Calcite was used as an internal standard

$b$ These reflections were used for the refinement of lattice parameters. Where ambiguity exists in the choice of $h k l$, decisions were made on the basis of intensities measured by Prewitt and Burnham (1966) in their solution of the crystal structure of jadeite

solid solution from $\mathrm{Jd}_{30}$ to $\mathrm{Jd}_{100}$. Champness (1973) notes the occurrence of antiphase domains in an omphacite with composition $\mathrm{Jd}_{31} \mathrm{Di}_{52} \mathrm{Ac}_{17}$. She speculated that the two narrow solvi may exist from $\mathrm{Jd}_{35}$ to $\mathrm{Jd}_{40}$, and $\mathrm{Jd}_{60}$ to $\mathrm{Jd}_{65}$, as a result of a transformation from a cation-disordered high-temperature structure with space group $C 2 / c$, to a structure with a primitive unit cell.

Phakey and Ghose (1973) also found antiphase domains in an omphacite $\left(\mathrm{Jd}_{39} \mathrm{Ac}_{10} \mathrm{Di}_{51}\right)$ and interpreted their cause as being due to complete local (to long range) order of octahedral cations.

The present chemical data, if indeed they are the result of a solvus, give a different miscibility gap than any previously proposed. Essene and Fyfe (1967) report that many pyroxenes from eclogites have compositions from $\mathrm{Jd}_{20}$ to $\mathrm{Jd}_{35}$ and thus plot across this gap, but these pyroxenes equilibrated at temperatures of 500 $600^{\circ} \mathrm{C}$, higher than the value of $300-400^{\circ} \mathrm{C}$ typical of blueschist occurrences. A solvus between $C$-centered and primitive pyroxenes could rapidly close off with increasing disorder and ultimate transformation of the primitive pyroxene to a $C$-centered phase at higher temperatures. No other interpretation supports the hypothesis that the St. Marcel pyroxenes are related by a solvus. No exsolution laminae were observed in either phase but the solvus limbs could be steep at low temperature or back reaction may be kinetically unfavorable. Unfortunately it is difficult to define a lowtemperature solvus experimentally because of sluggish reaction rates. In conclusion, we note that although the solvus relation is consistent with the data, it is by no means definitively established; work on these and other pyroxenes is necessary in order to positively define the solvus relations.

\section{Micas}

Two coexisting sheet silicates were observed in one specimen (no. 2), one pleochroic in shades of pink, and the other in yellow to brownish orange, (Table 1). Although it was first thought that the yellow phase was a manganoan stilpnomelane, subsequent qualitative microprobe analysis showed it to be a manganoan phlogopite and the pink mica to be a Si-rich dioctahedral mica. Because this occurrence of a trioctahedral mineral within the blueschist facies is the first reported ${ }^{2}$, and because the apparent coexistence of two phases provides new data on the nature of a two-mica solvus, we have characterized these phases in detail.

The results of wavelength dispersive electron microprobe analyses are listed in Table 2 for both micas. As is not unusual with micas, there is some ambiguity in the form of the normalized analyses due primarily to interpretations of cation oxidation states and octahedral site deficiencies. In the manganoan phlogopite, approximately $10-13 \%$ of the octahedral sites are occupied by $\mathrm{Mn}$. If it is assumed that no octahedral sites are vacant then the formula is:

$$
\begin{aligned}
& {\left[\mathrm{K}_{1.93} \mathrm{Na}_{0.02 \cdot 0.05}\right]\left[\mathrm{Mn}_{0.79}^{+2} \mathrm{Fe}_{0.08}^{+}{ }^{3} \mathrm{Ti}_{0.06} \mathrm{Mg}_{4.59} \mathrm{Al}_{0.47}\right]} \\
& \cdot\left[\mathrm{Si}_{6.38} \mathrm{Al}_{1.62}\right] \mathrm{O}_{20}\left[\mathrm{~F}_{0.56} \mathrm{OH}_{2.46} \mathrm{O}_{0.98}\right] .
\end{aligned}
$$

It is therefore an oxy-phlogopite with unusually high $\mathrm{Si}$ and low $\mathrm{Al}$ contents in the tetrahedral sites. If some of the $\mathrm{Mn}$ is trivalent, charge balance is maintained by increasing $\mathrm{O}$ at the expense of $\mathrm{OH}$, or creating octahedral site vacancies. Optically the phlogopite is very unusual in having a high $-2 \mathrm{~V}\left(85-90^{\circ}\right)$ rather than the low to medium $-2 V$ characteristic of micas previously known. $\mathrm{X}$ ray single-crystal and powder diffraction data was also obtained and this further confirmed the initial identification. Several single crystals all were determined to be the $1 \mathrm{M}$ polytype, with the lattice parameters of $a=5.33, b=9.17, c=10.25 \AA$ and $\beta=99.37^{\circ}$.

The pink mica is chemically similar to alurgite, the manganoan phengite, and is unusual for a potassium mica in being rather brittle, similar to fluor-phlogopite. Single-crystal X-ray analysis showed it to be the $3 \mathrm{~T}$ polytype with unit cell parameters $a=5.21$ and $c=29.69 \AA$. The analysis (Table 2) yields the following formula when normalized about 12 octahedrally and tetrahedrally coordinated cations:

$$
\begin{aligned}
& {\left[\mathrm{K}_{1.90} \mathrm{Na}_{0.01 \cdot 0.09}\right]} \\
& \cdot\left[\mathrm{Mn}_{0.04}^{+2} \mathrm{Mn}_{0.13}^{+3} \mathrm{Fe}_{0.06}^{+3} \mathrm{Ti}_{0.03} \mathrm{Mg}_{1.33} \mathrm{Al}_{2.42}\right] \\
& \cdot\left[\mathrm{Si}_{7.45} \mathrm{Al}_{0.55}\right] \mathrm{O}_{20}\left[\mathrm{~F}_{0.02} \mathrm{OH}_{3.98}\right] .
\end{aligned}
$$

It is very high in celadonite component and can be classed as a celadonitic phengite. It is unusual in being among the most celadonitic known from a metamorphic terrane ${ }^{3}$.

2 Duque, Essene and Peacor are currently working an occurrence of biotite in Shuksan blueschists of Washington

3 Essene and Ware (1970) report a phengite from a low-temperature eclogite having $\mathrm{Si}=7.5$ 


\section{Other Minerals}

Other minerals observed include braunite, quartz, microcline, albite, piedmontite, hollandite, apatite, strontian calcite and tremolite. The braunite from Sample 2 was analyzed, resulting in the formula:

$$
\begin{aligned}
& {\left[\mathrm{K}_{0.02} \mathrm{Ca}_{0.13} \mathrm{Mg}_{0.06} \mathrm{Mn}_{0.84}^{+2}\right]\left[\mathrm{Fe}_{0.06}^{+3} \mathrm{Mn}_{5.94}^{+3}\right]} \\
& \cdot\left[\mathrm{Si}_{0.94} \mathrm{Al}_{0,03}\right] \mathrm{O}_{12} .
\end{aligned}
$$

It coexists in equilibrium with hollandite and quartz as well as the other minerals in Sample 2.

The albite from Sample 2 has an average composition of $\mathrm{Na}_{0.98} \mathrm{Ca}_{0.01} \mathrm{Al}_{1.01} \mathrm{Si}_{2.99} \mathrm{O}_{8}$. The occurrence of $\mathrm{K}$-feldspar is unusual in the blueschist facies although Essene (1967) described and analyzed microcline in Franciscan meta-quartz keratophyres with albite + quartz + aegirine + jadeite, and Essene (1968) identified microcline in Alpine metarhyolites with the assemblage quartz + albite + jadeite. Duque, Essene and Peacor (in prep.) have located $\mathrm{K}$-feldspar in biotite-bearing Washington Blueschists. Although K-feldspar has often been regarded as unstable in the blueschist facies, these occurrences all indicate that it may be stable. The general lack of twinning, fine-grained anhedral crystals and paucity of $K$-rich rocks in the blueschist facies make it difficult to find $\mathrm{K}$-feldspar, and this may account for it not being more generally recognized.

The piedmontite has the approximate octahedral cation content $\mathrm{Al}_{0.6} \mathrm{Mn}_{0.3} \mathrm{Fe}_{0.1}$ and is strongly pleochroic in reds and oranges (Table 1). The hollandite is opaque and similar to braunite, and is difficult to identify without chemical information. Based on energy-dispersive electron microprobe analysis it appears to be stoichiometric $\mathrm{BaMn}_{8} \mathrm{O}_{16}$. The apatite is close to endmember $\mathrm{Ca}_{5}\left(\mathrm{PO}_{4}\right)_{3} \mathrm{~F}$. The carbonate has been identified as dominantly calcite by U-stage measurements with occasional cores that appear to be aragonite. Analyses yield strontium contents from 1 to $5 \%$ with an average formula $\left(\mathrm{Sr}_{0.03} \mathrm{Ca}_{0.97}\right) \mathrm{CO}_{3}$. The fibrous tremolitic amphibole has major $\mathrm{Ca}, \mathrm{Mg}$ and $\mathrm{Si}$ with minor $(1 \mathrm{wt} \%) \mathrm{Na}, \mathrm{Al}$ and $\mathrm{Fe}$, and trace $(0.1 \mathrm{wt} \%) \mathrm{K}, \mathrm{Ti}$ and $\mathrm{Mn}$. It appears to be a late replacement of pyroxene.

\section{Petrology}

The assemblage omphacite-quartz-albite is univariant if the jadeite component of the pyroxene is identified (Essene and Fyfe, 1967). It requires high pressures of 5-7 kb even at low temperatures of ca. $300^{\circ} \mathrm{C} \mathrm{(Fig.} \mathrm{2).}$ The exact stability of omphacite is still uncertain to \pm 1 to $2 \mathrm{~kb}$, as cation ordering on octahedral sites will reduce configurational entropy, and the possible solvus suggests that activity coefficients may deviate from 1. Essene (manuscript) has field evidence from Corsican blueschists that omphacite with albitequartz bears the same jadeite content as aegirinejadeite with albite-quartz. The latter system has been calibrated by Newton and Smith (1967) and by Popp and Gilbert (1972) and compares well with calculations by Essene and Fyfe (1967). The omphacite curves in Figure 2 were obtained using the 1-site model applicable to aegirine-jadeite, recalculating the curves from the stability of jadeite-quartz-low albite from Newton

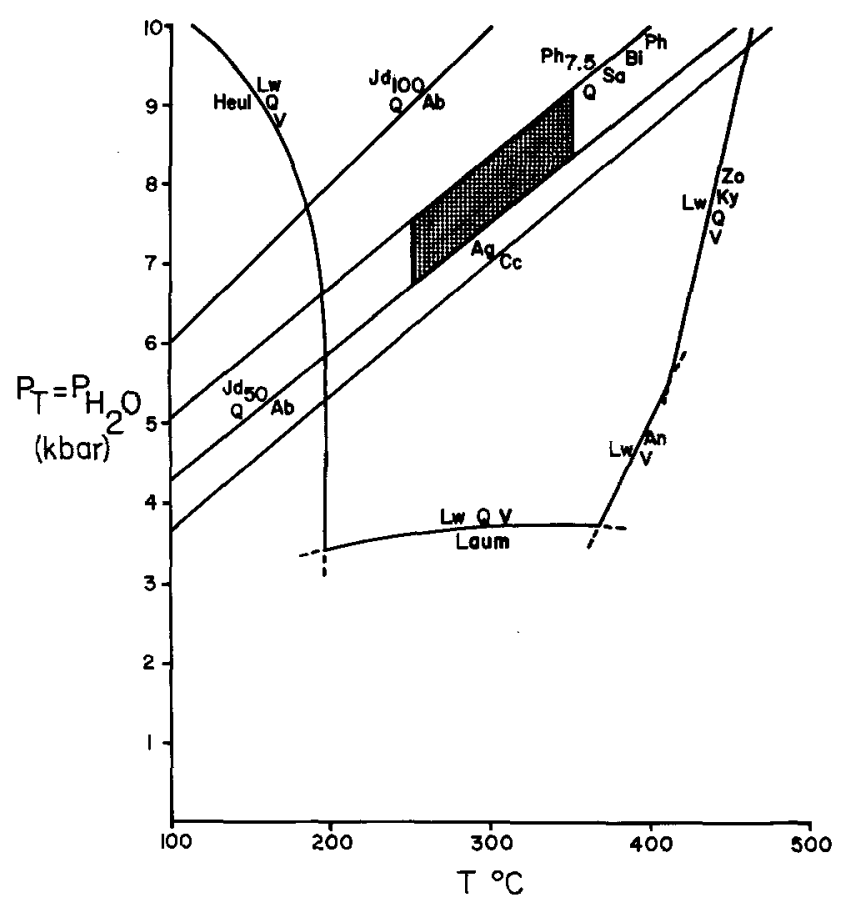

Fig. 2. $P-T$ diagram for some pertinant blueschist equilibria. See text for discussion of curves

and Smith (1967) and using the cell volume for jadeite from Prewitt and Burnham (1966).

The phengite component of muscovite defines a $P-T$ line when equilibrated with biotite-quartz-Kfeldspar-water vapor (Velde, 1965). This assemblage is found in Sample 2; the Mn content of the phlogopite and muscovite is assumed to have a negligible effect on the equilibrium. If the largely unreversed experiments of Velde are applied, they require the same high $P$ and low $T$ conditions as do the pyroxene data. As Velde has shown, the $+\Delta \mathrm{V}_{s}$ of this reaction means that quite variable water pressure has little effect on the equilibrium. The infered $P-T$ line for the phengite stability lies close to the stability limit of omphacite (Fig. 2), gratifying in view of the uncertainties involved.

The mutual lack of miscibility of microcline and albite require temperatures of $<350^{\circ} \mathrm{C}$. The mutual solubility of albite $\left(\mathrm{Ab}_{98} \mathrm{An}_{1} \mathrm{Or}_{1}\right)$ and the microcline $\left(\mathrm{Ab}_{3} \mathrm{An}_{0} \mathrm{Or}_{97}\right)$ are dependent on temperature and to a lesser extent pressure (e.g. Barth, 1951). Experimental calibration of this solvus at low temperatures has been hindered by difficulties in obtaining maximum order in the experimental feldspars. Recent work of Luth et al. (1972), Goldsmith and Newton (1972), and Whitney and Stormer (1977) suggest that microcline $\left(\mathrm{Or}_{96}\right)$ and albite $\left(\mathrm{Ab}_{99}\right)$ should equilibrate at temperatures of $350 \pm 50^{\circ} \mathrm{C}$ for $8 \mathrm{kbar}$ pressure. Combinations of these temperatures with the stability 
limit of the phengite and omphacite + quartz gives an estimated pressure of $8 \pm 1 \mathrm{kbar}$ (Fig. 2). These $P-T$ estimates are consistent with the stability of albite and lawsonite known from St. Marcel (Fig. 2).

The strontian calcite should in principle give restrictions as to $P-T$ (Fig. 2). Froese and Winkler (1966) and Froese (1970) have attempted to calibrate the system $\mathrm{SrCO}_{3}-\mathrm{CaCO}_{3}$ and the graphs suggest that $5 \% \mathrm{Sr}$ will stabilize aragonite by $1 \mathrm{kbar}$. The Ustage measurements of the St. Marcel carbonates do not conclusively prove the presence of aragonite cores in the calcite; the occasional biaxial areas may have been simply strained calcite. This strain would be consistent with a 3 to $5 \% \mathrm{Sr}$ content in the rhombohedral phase and argues for a primary orthorhombic carbonate which has nearly totally inverted to the present calcite. As inversion is the rule rather than the exception for blueschist aragonite, the occurrence of calcite rather than aragonite cannot be used to limit the $P-T$ stability. At temperatures of $300 \pm 50^{\circ} \mathrm{C}$ aragonite with $5 \% \mathrm{Sr}$ requires pressures $>6 \mathrm{kbar}$ (Froese, 1970).

The assemblage braunite +quartz requires high $f \mathrm{O}_{2}$ in order to be stabilized over other Mn silicates (Muan, 1959; Huebner, 1967, 1977). An estimation of required $\mathrm{fO}_{2}$ at low temperatures can be made assuming Muan's equilibrium point for the reaction braunite + quartz $=$ rhodonite + oxygen at $T=1150^{\circ} \mathrm{C}$ and $P_{2}=1 \mathrm{~atm}$. This calculation requires an estimation of the entropy of braunite. This is obtained using summation techniques (Fyfe and Verhoogen, 1958):

$S\left(\mathrm{Mn}_{7} \mathrm{SiO}_{12}\right)=S\left(\mathrm{MnSiO}_{3}\right)+3 S\left(\mathrm{Mn}_{2} \mathrm{O}_{3}\right)+0.6 \Delta V$.

Using this technique in combination with Muan's experimental point, one may calculate the free energy for braunite at low temperatures; we estimate $\Delta G_{700^{\circ} \mathrm{K}}^{0}$ (Braunite) $=-844 \mathrm{kcal}$. Combining these data with $\Delta G_{T}^{0}$ for rhodonite and quartz (Robie and Waldbaum, 1968) allows calculation of $f \mathrm{O}_{2}$ from the equation:

$\Delta G_{T}^{P}=\Delta G_{T}+\Delta V_{s} \Delta P+R T \ln \frac{f \mathrm{O}_{2}^{3} a_{\mathrm{Br}}^{2} a_{\mathrm{QZ}}^{12}}{a_{\mathrm{Rh}}^{14}}$

for the reaction:

Quartz + Braunite $=$ Rhodonite + Oxygen
$12 \mathrm{SiO}_{2}+2 \mathrm{Mn}_{7} \mathrm{SiO}_{12}=14 \mathrm{MnSiO}_{3}+3 \mathrm{O}_{2}$

if we can assume $a=X$. The impurities in braunite and rhodonite will affect the $f \mathrm{O}_{2}$. To evaluate their effect, a knowledge of the $K_{D}$ of $\mathrm{Mn}, \mathrm{Ca}, \mathrm{Mg}, \mathrm{Fe}^{2+}$ between braunite and rhodonite is needed. Since this data is unavailable, we will, of necessity, neglect the effect of impurities for this sample. The results are

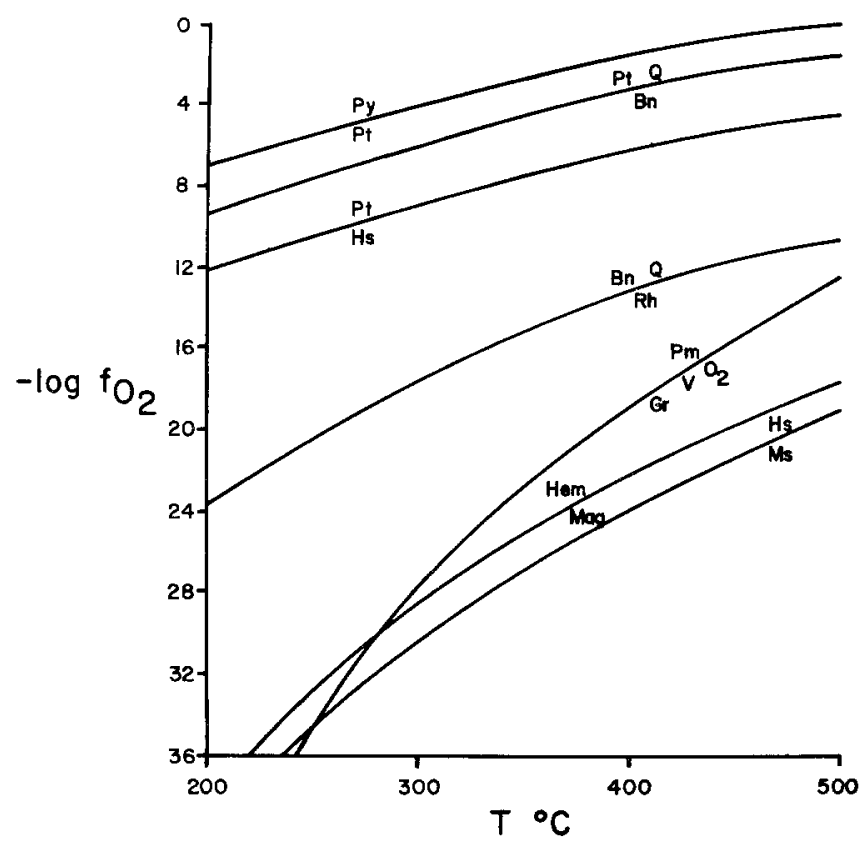

Fig. 3. $8 \mathrm{kbar}, f \mathrm{O}_{2}-T$ plot of the stability of braunite and piedmontite in comparison with the stabilities of common $\mathrm{Fe}$ and $\mathrm{Mn}$ oxides. $P y=$ pyrolusite, $P t=$ partridgeite, $H S=$ hausmannite, $M s$ = manganosite, $B n=$ braunite, $G r=$ garnet, $P m=$ piedmontite, $R h$ $=$ rhodonite

shown in Figure 3. The assemblage braunite + quartz requires $f \mathrm{O}_{2}$ of $>10^{-17}$ at $300^{\circ} \mathrm{C}$, well within the stability of hematite and hausmanite. This compares well with estimations by Huebner (1967) who estimated a minimal $f \mathrm{O}_{2}$ of $10^{-12}$ for braunite-quartz at $300^{\circ} \mathrm{C}$. These oxygen fugacities are much higher than those of ordinary rocks and are confirmed by the presence of piedmontite which requires high $f \mathrm{O}_{2}$ to be stabilized (Keskinen and Liou, 1976). The stability of piedmontite vs. garnet $\left(\mathrm{Gr}_{2} \mathrm{Sp}_{1}\right)$ was calculated from their data making similar entropy estimations as above and correcting to $8 \mathrm{kbar}$ (Fig. 3). The initial deposit must have been made of highly oxidized $\mathrm{Mn}$ minerals such as are found in Mn-nodules or some hydrothermal veins, and the $f \mathrm{O}_{2}$ of the deposit must have remained relatively high throughout metainorphism.

Acknowledgments. We thank Professor W.C. Bigelow, Larry Allard, John Mardingly and Peggy Hollingsworth of the University of Michigan Microprobe Laboratory for continuing help and upkeep of the electron microprobe. We are also grateful to Gary Winter for some of the analytical work. This work was supported in part by NSF Grant 014753 to Eric J. Essene.

\section{References}

Barth, T.F.W.: The feldspar geologic thermometers. N.Jb. Mineral. Abh. 82, 143-154 (1951) 
Bell, P.M., Davis, B.T.C.: Temperature-composition section for jadeite-diopside. Carnegie Inst. Wash. Year Book 64, 120-123 (1964)

Bell, P.M., Davis, B.T.C.: Investigation of a solvus in the system jadeite-diopside. Carnegie Inst. Wash. Year Book 65, 239-241 (1965)

Burnham, C.W.: Lattice constant refinement. Carnegie Inst. Wash. Year Book 61, 132-135 (1961)

Champness, P.E.: Speculation on an order-disorder transformation in omphacite. Am. Mineralogist 58, 540-542 (1973)

Clark, J.R., Papike, J.J.: Crystal-chemical characterization of omphacites. Am. Mineralogist 53, 840-868 (1968)

Coleman, R.G., Clark, J.R.: Pyroxenes in the blueschist facies of California. Am. J. Sci. 266, 43-59 (1968)

Dana, E.S.: Descriptive mineralogy. NewYork: John Wiley and Sons, Inc. 1892

Doelter, C.A.: Handbuch der Mineralchemie, Vol.2. Dresden und Leipzig: Verlag von Theodor Steonkopff 1912

Ernst, W.G.: Significance of phengitic micas from low-grade schists. Am. Mineralogist 48, 1357-1373 (1963)

Ernst, W.G.: Interpretative synthesis of metamorphism in the Alps. Bull. Geol. Soc. Am. 84, 2053-2078 (1973)

Essene, E.J.: Petrogenesis of Franciscan metamorphic rocks. Ph.D. Thesis, Univ. of California, Berkeley, CA (1967)

Essene, E.J.: Relatively pure jadeite from a siliceous Corsican gneiss. Earth Planet. Sci. Lett. 5, 270-272 (1968)

Essene, E.J., Fyfe, W.S.: Omphacite in Californian metamorphic rocks. Contrib. Mineral. Petrol. 15, 1-23 (1967)

Essene, E.J., Ware, N.G.: The low temperature xenolithic origin of eclogites in diatremes, N.E. Arizona (abstr.). Geol. Soc. Am. Abstr. Progr. 2, 547-548 (1970)

Froese, E.: Calculated phase relations in the system $\mathrm{CaCO}_{3}$ $-\mathrm{SrCO}_{3}$. Can. Mineralogist 10, 665-676 (1970)

Froese, E., Winkler, H.G.F.: The system $\mathrm{CaCO}_{3}-\mathrm{SrCO}_{3}$ at high pressures and $500^{\circ} \mathrm{C}$ to $700^{\circ} \mathrm{C}$. Can Mineralogist 8, 551-566 (1966)

Fyfe, W.S., Verhoogen, J.: General thermodynamic considerations. In: Metamorphic reactions and metamorphic facies (W.S. Fyfe et al., eds.). Geol. Soc. Am. Mem. 73, 25-34 (1958)

Goldsmith, J.R., Newton, R.C.: An experimental determination of the alkali feldspar solvus. In: The feldspars (W.S. Mackenzie and J.Zussman, eds.), pp. 337-359. Manchester; England: Manchester University Press 1974

Hintze, C.: Handbuch der Mineralogie, Vol. 2. Leipzig: Verlag Von Vert and Comp. 1897
Huebner, J.: Stability relations of minerals in the system $\mathrm{Mn}-\mathrm{Si}$ $-\mathrm{C}-\mathrm{O}$. Ph.D. Thesis. Baltimore, Maryland: Johns Hopkins University 1967

Huebner, J.: The manganese oxides-A bibliographic commentary. In: Oxide minerals (D. Rumble, ed.), pp. SH1-SH17. Mineral. Soc. Am. Short Course Notes 1977

Keskinen, M.J., Liou, J.G.: Synthesis and stability relations of Piedmontite, $\mathrm{Ca}_{2} \mathrm{MnAl}_{2} \mathrm{Si}_{3} \mathrm{O}_{12}(\mathrm{OH})$ (abstr.). Geol. Soc. Am. Abstr. Progr. 8, 953-954 (1976)

Kushiro, I.: Clinopyroxene solid solutions at high pressures. Carnegie Inst. Wash. Year Book 64, 112-117 (1964)

Lorenzoni, S.: Studio geo-petrografico del versante Italiano del Massiccio D'Ambin. Memorie degl. Inst. Geol. Mineral. Univ. Padora 25, 88 p. (1965)

Luth, W.C., Fenn, P.M.: Peralkaline feldspar solvi. In: The feIdspars (W.S. MacKenzie and J.Zussman, eds.), pp. 297-312. Manchester, England: Manchester University Press 1974

Muan, A.: Stability relations among some manganese minerals. Am. Mineralogist 44, 946-960 (1959)

Newton, R.C., Smith, J.V.: Investigations concerning the breakdown of albite at depth in the earth. J. Geol. 75, 268-286 (1967)

Phakey, P.P., Ghose, S.: Direct observation of anti-phase domain structure in omphacite. Contrib. Mineral. Petrol. 39, 239-245 (1973)

Plas, L. Van der: Petrology of the Northern Adula Region, Switzerland, (with particular reference to glaucophane-bearing rocks). Leidse Geol. Mededel. 24, 415-602 (1959)

Popp, R.K., Gilbert, M.C.: Stability of acmite-jadeite pyroxenes at low pressure. Am. Mineralogist 57, 1210-1231 (1972)

Prewitt, C.T., Burnham, C.W.: The crystal structure of jadeite; $\mathrm{NaAlSi}{ }_{2} \mathrm{O}_{6}$. Am. Mineralogist 51, 956-975 (1966)

Robie, R.A., Waldbaum, D.R.: Thermodynamic properties of minerals and related substances at $298.15^{\circ} \mathrm{K}$ and one atmosphere pressure and at higher temperatures. U.S. Geol. Surv. Bull. 1259, 256 p. (1968)

Velde, B.: Phengitic micas: Synthesis, stability and natural occurrence. Am. J. Sci. 263, 886-913 (1965)

Whitney, J.A., Stormer, J.C.: The distribution of $\mathrm{NaAlSi}_{3} \mathrm{O}_{8}$ between coexisting microcline and plagioclase and its effect on geothermometric calculations. Am. Mineralogist 62, 687-691 (1977)

Accepted April 11, 1978 